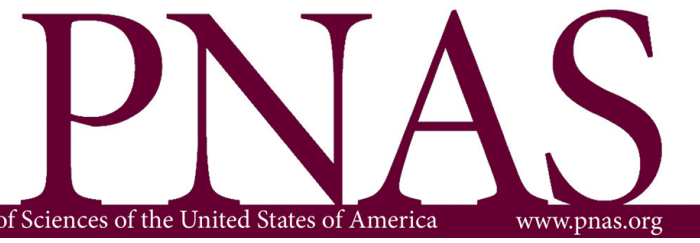

\title{
Evidence for a Ring Structure of Polyoma Virus DNA
}

R. Dulbecco, and M. Vogt

PNAS 1963;50;236-243

doi:10.1073/pnas.50.2.236

This information is current as of December 2006.

\begin{tabular}{|ll|}
\hline & $\begin{array}{l}\text { This article has been cited by other articles: } \\
\text { www.pnas.org\#otherarticles }\end{array}$ \\
E-mail Alerts & $\begin{array}{l}\text { Receive free email alerts when new articles cite this } \\
\text { article - sign up in the box at the top right corner of } \\
\text { the article orclick here. }\end{array}$ \\
& $\begin{array}{l}\text { To reproduce this article in part (figures, tables) or } \\
\text { in entirety, see: } \\
\text { www.pnas.org/misc/rightperm.shtml } \\
\text { Rights \& Permissions }\end{array}$ \\
To order reprints, see: \\
www.pnas.org/misc/reprints.shtml
\end{tabular}

Notes: 


\title{
EVIDENCE FOR A RING STRUCTURE OF POLYOMA VIRUS DNA*
}

\author{
By R. Dulbecco† and M. Vogt $\dagger$ \\ CALIFORNIA INSTITUTE OF TECHNOLOGY
}

Communicated June 11, 1963

The DNA of polyoma (PY) virus has two interesting features: it is unusually resistant to heat or formamide denaturation, ${ }^{1}$ and it has two distinct components, of sedimentation coefficient 14 and 21, respectively. ${ }^{2}$ A two-component sedimentation was formerly shown to be a characteristic of the DNA of papilloma virus, ${ }^{3}$ which is considered a member of the same group of viruses.

Evidence presented in this article shows that both these features of polyoma virus DNA are the consequence of special configurational properties.

Material and Methods.-Purified polyoma virus was prepared according to Winocour; 4 DNA was extracted from the purified virus with phenol ${ }^{5}$ and stored at $-70^{\circ} \mathrm{C}$. Virus labeled with either $\mathrm{P}^{32}$ or $\mathrm{H}^{3}$ was obtained by adding label ( $\mathrm{P}^{32}$ orthophosphate or $\mathrm{H}^{3}$ thymidine) $24 \mathrm{hr}$ after infecting the cultures. Sedimentation studies were carried out by the band sedimentation method: $3 \mathrm{ml}$ of $\mathrm{CsCl}$ solution of density 1.50 were placed in a centrifuge tube and covered with paraffin oil; the sample, of a volume $0.05-0.25 \mathrm{ml}$. was added dropwise on top of the oil layer. The tube was spun in an SW-39 rotor in a model L Spinco ultracentrifuge at $35 \mathrm{~K} \mathrm{rpm}$; in most experiments, spinning time was $4 \mathrm{hr}$. For shorter runs, the tube containing the $\mathrm{CsCl}$ solution and oil was spun for $4 \mathrm{hr}$ before adding the sample, in order to preform the gradient. The $\mathrm{CsCl}$ solution was buffered either at $\mathrm{pH} 7.5$ with $0.01 M$ Tris, or at alkaline $\mathrm{pH}\left(11.0,11.8\right.$, and 12.5) with $0.01 M$ phosphate buffer. ${ }^{7}$ For density gradient equilibrium sedimentation, $3 \mathrm{ml}$ of a $\mathrm{CsCl}$ solution of density 1.71 or 1.72 at $\mathrm{pH} 7.5$, and 1.73 at $\mathrm{pHs}$ 11-12.5 were used. The solution was covered with oil, spun in the SW39 head of the model $\mathrm{L}$ ultracentrifuge at 29 or $30 \mathrm{~K}$ for $70-80 \mathrm{hr}$. In all cases, fractions were collected from the bottom of the tube. Columns of methylated albumin were prepared according to Mandell and Hershey. ${ }^{8}$ Infectivity of polyoma DNA was measured as described by Weil. ${ }^{5}$ Pancreatic DNAase Worthington 1x crystallized was used. E. coli phosphodiesterase (Lehman enzyme $)^{9}$ was a gift of Dr. R. L. Sinsheimer. DNAase and phosphodiesterase digestion were carried out according to Fiers and Sinsheimer. ${ }^{16}$

Results.-In brief, the following results were obtained. (1) PY DNA always sediments in two bands, a fast one $(F)$ and a slow one $(S)$. The $F$ and $S$ components are stable under a variety of conditions; both are infectious. (2) In the column of methylated albumin the $S$ component is eluted at higher salt concentration than the $F$ component. (3) The following observations were made by density gradient equilibrium centrifugation. At $\mathrm{pH} 7.5$ the bands formed by the $F$ and by the $S$ component have the same density and do not differ greatly in width; at $\mathrm{pH} 11.8$ most of the $F$ component has the density of native DNA, whereas the $S$ component has the density of denatured DNA. At pH 12.5 both components are denatured; the $S$ component forms a wider band. (4) In band sedimentation at $\mathrm{pH} 12.5$ the $F$ component sediments about 2.5 times faster than at $\mathrm{pH} 7.5$; after neutralization and annealing it reacquires the original sedimentation characteristics. The $S$ component, on the contrary, migrates at $\mathrm{pH} 12.5$, about the same speed as at $\mathrm{pH} 7.5$. (5) The infectivity of the $F$ component is increased several times after treatment at pH 12.5 followed by neutralization; the infectivity of the $S$ component is lost after this treatment. (6) Pancreatic DNAase converts the $F$ component into the $S$ component, with loss of infectivity. The kinetics of conversion is unusual, since it is of first order. These results show that molecules of polyoma virus DNA in different 
states exist in the $F$ and in the $S$ component. The data are consistent with the hypothesis that the $F$ component is made up of molecules in ring form, and the $S$ component of molecules in linear, or open, form. The results will now be given in greater detail, in terms of this hypothesis.

Properties of the two components of different sedimentation velocity: Many preparations of PY DNA, of both small plaque and large plaque type, were examined by band sedimentation in $\mathrm{CsCl}$ at $\mathrm{pH}$ 7.5. They all contained the $F$ and the $S$ band. The band pattern observed with this method was found to be similar to that observed with the sucrose gradient method. The major component was the $F$ component; it represented 60-80 per cent of the total in DNA preparations which had been extracted only once with phenol, and 90-95 per cent in preparations which had been extracted two or three times.

The ratio of the uncorrected distances traveled by the two components was 1.31 in sucrose gradient with $5 \times 10^{-3} M \mathrm{Mg}^{++}, 2.5 \times 10^{-2} \mathrm{M} \mathrm{K} \mathrm{K}^{+}$, and $5 \times 10^{-2} \mathrm{M}$ Tris buffer, $\mathrm{pH} 7.5$; the ratio was 1.22 in $\mathrm{CsCl}$ of density 1.50 at $\mathrm{pH} 7.5$.

Both components were infectious and produced plaques of equal type. The average specific infectivity (ratio: infectivity to $\mathrm{OD}_{260}$ ) was two to three times larger in the $F$ band (Fig. 1). In the $F$ band the infectivity was distributed almost uniformly, whereas in the $S$ band infectivity was present only in the frontal part. The $S$ band is thus heterogeneous; this band is assumed to consist in its frontal part of infectious linear molecules, obtained by opening the ring, and in its trailing part, of smaller noninfectious fragments.

Stability: Isolated $F$ and $S$ components were prepared, either unlabeled or labeled with different labels, by collecting fractions corresponding to the peak

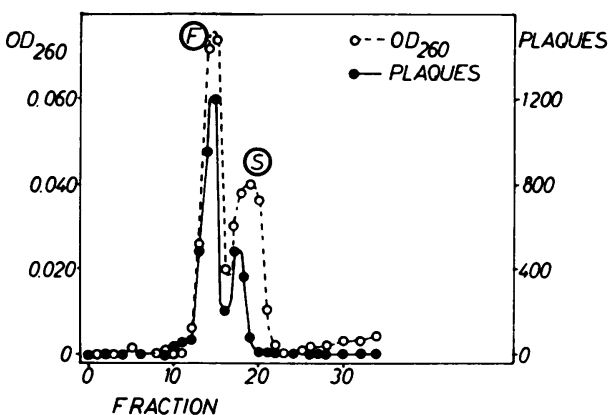

Fig. 1.-Band sedimentation of polyoma DNA at $\mathrm{pH}$ 7.5. Polyoma DNA extracted once with phenol and sedimented at $35 \mathrm{~K} \mathrm{rpm}$ in $\mathrm{CsCl}$ of density 1.50 for $4 \mathrm{hr}$. part of each band. The $F$ and $S$ components prepared in this way maintained their characteristic sedimentation velocities after prolonged storage at $-70^{\circ} \mathrm{C}$. Neither conversion from one to the other nor alterations of their sedimentation properties were obtained by the following treatments: exposure to $\mathrm{pHs}$ from 4.5 to 11 , or to $6 \mathrm{M} \mathrm{CsCl}$; treatment with 2 per cent $\mathrm{Na}$-dodecylsulfate for $30 \mathrm{~min}$ at room temperature; annealing separately or together at $70^{\circ} \mathrm{C}$ for up to $1 \mathrm{hr}$; chromatography in a column of methylated albumin; treatment with the Lehman enzyme.

Chromatographic properties: $\mathrm{P}^{32}$-labeled isolated $F$ and $S$ components mixed with unfractionated $\mathrm{H}^{3}$-labeled PY DNA were chromatographed in the column of methylated albumin (Fig. 2). The $F$ component was distributed almost uniformly throughout the whole elution band; the $S$ component eluted at higher salt concentration. In turn, the frontal part of the elution band was rich in the fast component, whereas the trailing part was richer in the slow component. The infectivity was distributed almost uniformly throughout the chromatographic band. 


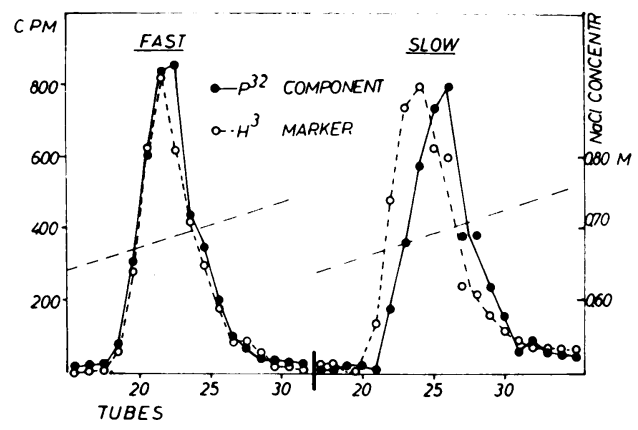

Fig. 2.-Chromatography of $F$ and $S$ components on a column of methylated albumin. 0.5 $\mu \mathrm{g}$ of DNA was used in each run. A column of 1 $\mathrm{cm}$ diameter, $11 \mathrm{~cm}$ long was used. The DNA was applied in $0.55 M \mathrm{NaCl}, 0.05 M$ phosphate buffer $\mathrm{pH}$ 6.9. The elution gradient was linear. Fractions of $2 \mathrm{ml}$ each were collected. To each fraction $0.03 \mathrm{ml}$ of a $4 \%$ serum albumin solution and trichloroacetic acid to a final concentration of $5 \%$ were added in the cold. After centrifugation the pellets were dissolved in $\mathrm{NH}_{4} \mathrm{OH}$ and counted.

These results contradict the hypothesis that the $S$ band is made up of monomer DNA molecules and the $F$ band of end-to-end dimers, as suggested by Watson and Littlefield ${ }^{3}$ for the two components of papilloma virus DNA of different sedimentation velocity: the dimers should in fact elute at higher, rather than lower, salt concentration. The results are compatible with the ring hypothesis, since the linear molecules may well appear longer to the column than the ring molecules.

Density gradient equilibrium centrifugation: Mixtures of $F$ and $S$ components, labeled with different isotopes, were banded at $\mathrm{pHs} 7.5,11,11.8$, and 12.5. At $\mathrm{pH} 7.5$ the two components gave rise to essentially coincident bands at equilibrium (Fig. 3); the band of the $S$ component was wider by a factor of 1.2 , perhaps owing to the presence, in this component, of fragments of DNA molecules. The $S$ component reached equilibrium more slowly than the $F$ component. At $\mathrm{pH} 11$ both components had the buoyant density of native PY DNA, although

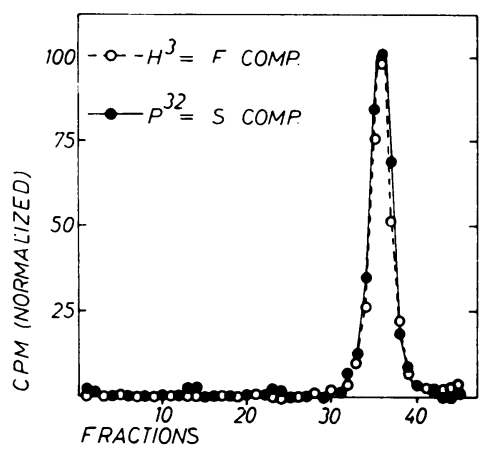

FIG. 3.-Density gradient equilibrium centrifugation of $F$ and $S$ components at $\mathrm{pH}$ 7.5. $\mathrm{H}^{3}$-labeled DNA containing ca. $90 \% \mathrm{~F}$ component, and $\mathrm{P}^{32}-$ labeled DNA containing ca. $80 \% \mathrm{~S}$ component, in amounts of $0.2 \mu \mathrm{g}$ each, were centrifuged in $\mathrm{CsCl}$ of density 1.72 in $0.01 M$ Tris buffer of $\mathrm{pH} 7.5$ for $80 \mathrm{hr}$ at $29 \mathrm{~K} \mathrm{rpm}$.

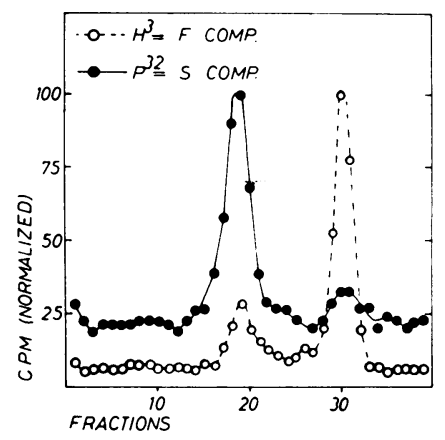

FIG. 4.-Density gradient equilibrium centrifugation of $F$ and $S$ components at $\mathrm{pH} 11.8$. $\mathrm{H}^{3}$-labeled $F$ and $\mathrm{P}^{32}$-labeled $S$ component in $0.1 M$ phosphate buffer at $\mathrm{pH} 11.8$ were centrifuged in $\mathrm{CsCl}$ solution of density 1.73 in $0.01 M$ phosphate buffer, $\mathrm{pH} 11.8$, for $80 \mathrm{hr}$ at $30 \mathrm{~K}$ rpm.

the band made up of the $S$ component tended to spread toward higher densities, owing to incipient denaturation. At $\mathrm{pH} 12.5$ both components were completely denatured and had a correspondingly higher density $;^{7}$ the band of the $S$ component was 1.5 times wider than that of the $F$ component. At $\mathrm{pH} 11.8$ the $S$ component had a denatured density, whereas the $F$ component separated into two bands, with 
most of the DNA in a band of native density, and the remainder in a band of denatured density (Fig. 4). The proportion of F DNA in these bands differed in various preparations.

Band sedimentation at $p H$ 12.5: The $S$ component sedimented at a speed not very different from that which it had at $\mathrm{pH} 7.5$, whereas the $F$ component gave rise to two bands, one ( $S F$ band) sedimenting like the $S$ component at the same $\mathrm{pH}$, the other ( $F F$ band) sedimenting about 2.5-2.8 times faster (Fig. 5). The proportion of $F$ DNA which appeared in the $F F$ band was similar to that resisting denaturation in the equilibrium centrifugation. The DNA of the $F F$ band reacquired the sedimentation velocity of $F$ DNA when annealed at $\mathrm{pH} 11.8$ in $6 \mathrm{M} \mathrm{CsCl}$ : when rapidly neutralized, most of the $F F$ DNA retained the high sedimentation velocity.

The results obtained at alkaline $\mathrm{pH}$ are interpreted as follows: the ring molecules ( $F$ component) are resistant to denaturation, presumably because they do not have free ends; when denatured, they remain topologically unchanged, i.e., still coiled together, and sediment very rapidly, like incompletely denatured DNA. ${ }^{11}$ Upon annealing, they reconstitute the ring molecules characteristic of the $F$ component. The linear molecules ( $S$ component) denature more readily, presumably because they have free ends; upon denaturation they give rise to separate single strands, which sediment at a rate similar to that of the native $S$ component. The molecules of the $F$ component, which sediment slowly at $\mathrm{pH} 12.5$ ( $S F$ band) and denature readily, are thought to originate from $F$ molecules either with single-chain cuts, or with alkali-labile points, such as pre-existing depurinations. Upon denaturation, such molecules would give rise both to single-stranded rings and single-stranded linear chains, which would move close to each other, like the analogous $\phi \mathrm{X}$ forms. ${ }^{12}$

Behavior of the infectivity at alkali $p H$ : Treatment at pH 11.8 or 12.5 abolished the infectivity of the $S$ component. The infectivity of the $F$ component was not affected by treatment at $\mathrm{pH} 11.8$; after treatment at $\mathrm{pH} 12.5$ and rapid neutralization it was increased about four times. This increase can be probably attributed to increased uptake of partially denatured DNA by the cells. ${ }^{1}$

The two bands produced by the $F$ component when sedimented at $\mathrm{pH} 12.5$ were both infectious; in the $S F$ band the specific infectivity (ratio: infectivity to radioactivity) was maximal in the frontal and absent in the trailing part of the band.

These results show that the $S F$ band is heterogeneous. The heterogeneity is also shown by the different sensitivity to the Lehman enzyme of the various fractions composing the band. The DNA present in the frontal part of the band was resistant to the enzyme, whereas that of the trailing part was partly hydrolyzed. The infectivity was not affected by the enzyme. A possible interpretation of these results is that the infectious DNA present in the frontal part of the $S F$ band is made up of single-stranded rings, and the DNA of the trailing part, mostly noninfectious, of single-stranded linear chains. Other interpretations are, however, possible.

DNAase digestion: Samples of the labeled isolated components were treated with the enzyme at constant concentration for various lengths of time. Then the sedimentation pattern of each sample was determined, after mixing it with differentially labeled unfractionated PY DNA as marker. F component (Fig. 6): As a function of the time of digestion the height of the $F$ band decreased, and a band coincident with the native $S$ band was formed. The change affected the height of the $F$ band but not its position. No component migrating at a velocity intermediate between 


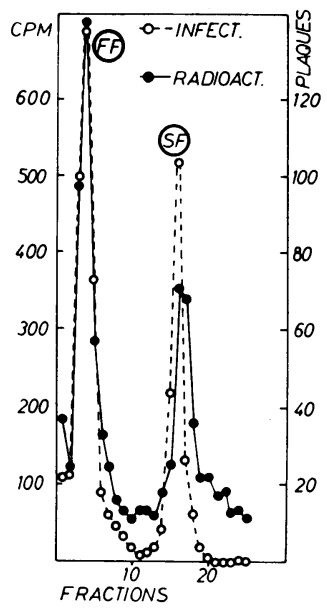

FIG. 5.-Band sedimentation of the $F$ component at $\mathrm{pH} \quad 12.5$. $0.2 \mu \mathrm{g}$ of $\mathrm{H}^{3}$-labeled PY DNA, made up almost exclusively of $F$ component, was mixed with $1.5 \mu \mathrm{g}$ of unlabeled isolated $F$ component, and brought to pH 12.5 with $0.1 M$ phosphate buffer. The mixture was sedimented at 35 $\mathrm{K} \mathrm{rpm}$ for two $\mathrm{hr}$ in a tube containing $\mathrm{CsCl}$ of density 1.50 , in $0.01 M$ phosphate buffer, pH 12.5. The tube had been prespun for $4 \mathrm{hr}$ at $35 \mathrm{~K}$ rpm in order to preform the gradient. Both radioactivity and infectivity were determined in all fractions.

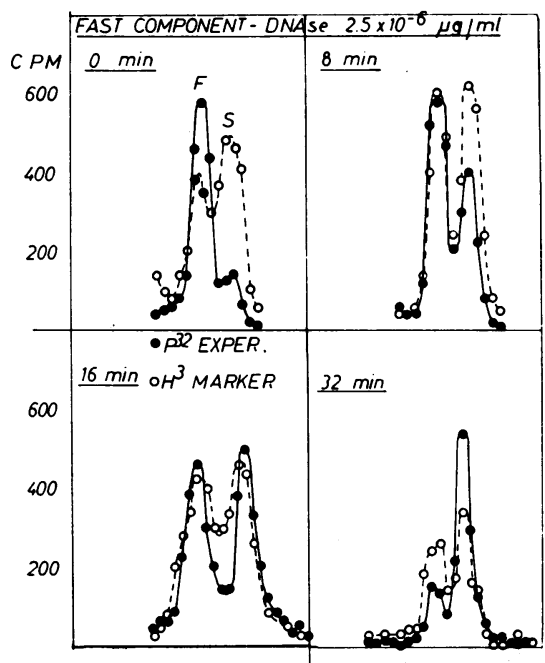

Fig. 6.-Action of DNAase on the $F$ component. Isolated $\mathrm{P}^{32}$-labeled $F$ component DNA $(0.5 \mu \mathrm{g} / \mathrm{ml})$, unfractionated unlabeled PY DNA $(4 \mu \mathrm{g} / \mathrm{ml})$, and DNAase, pre-equilibrated at $37^{\circ} \mathrm{C}$, were mixed at time zero and incubated at $37^{\circ} \mathrm{C}$ for various lengths of time. The incubation medium was: $0.04 M \mathrm{NaCl}, 0.01 M$ Tris

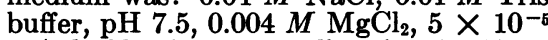
$\mathrm{gr} / \mathrm{ml}$ of bovine serum albumin. DNAase action was interrupted by $0.008 M$ Versene and $0.2 \mathrm{M}$ phosphate buffer of pH 9.0. Each sample was then mixed with unfractionated $\mathrm{H}^{3}$-labeled PY DNA, and sedimented at $35 \mathrm{~K} \mathrm{rpm}$ for $4 \mathrm{hr}$ in $\mathrm{CsCl}$ of density 1.50 .

those of the $F$ and of the $S$ band was formed. In the further study of this phenomenon, a DNAase treatment which converts 37 per cent of the $F$ component into $S$ will be designated as a "converting hit." $S$ component (Fig. 7): As a function of the time of digestion the $S$ band at first increased in width, and showed subsequently a progressively lower velocity of sedimentation without generating a new separate band.

The results obtained with the $F$ component can be interpreted as those obtained by Fiers and Sinsheimer ${ }^{13}$ with the DNA of phage $\phi \mathrm{X} 174$ : that a single scission in the ring molecule converts it to the linear form, thus causing a discrete difference in sedimentation velocity.

Kinetics of DNAase digestion: In repeated experiments the kinetics of disappearance of the $F$ band as a function of time, at constant DNAase concentration, was found of first order. This result suggested at first that the ring contains an inserted single-stranded segment. To search for such a segment, labeled $F$ DNA was exposed to several converting hits with DNAase and then to the Lehman enzyme. No measurable hydrolysis was observed under conditions where 1 per cent hydrol- 
ysis could have been detected. We conclude that the DNA of the $F$ component does not have a single-stranded segment of sufficient size to explain the kinetics of DNAase action.

In order to interpret the kinetics of $F \rightarrow$ $S$ conversion, the kinetics of DNAase action on either component was studied by sedimenting the enzyme-treated DNA both at $\mathrm{pH} 7.5$ and at pH 12.5, together with untreated DNA, differentially labeled. The changes in sedimentation velocity at $\mathrm{pH} 7.5$ reflect the consequences of complete scissions of the DNA molecules; the changes observed at $\mathrm{pH} 12.5$ reflect the consequences of singlechain scissions. The following observations were made. $F$ component: The effect of DNAase, whether studied at $\mathrm{pH} 7.5$ or 12.5 , was similar: at $\mathrm{pH} 12.5$ the $F F$ component

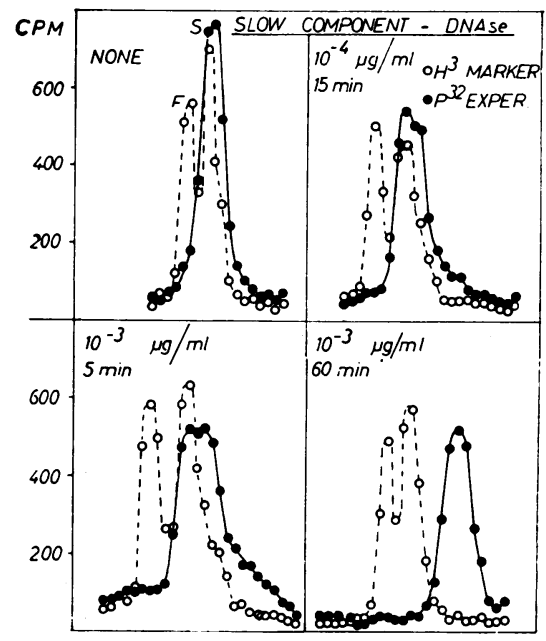

Fig. 7.-DNAase action on the $S$ component. Same conditions as in Fig. 6, except that isolated $S$ component was used. was converted into the $S F$ component at exactly the same rate at which the $F$ component was converted into the $S$ component at pH 7.5. This result shows that DNAase did not produce single-chain cuts in the ring molecules, which would have resulted in faster disappearance of the $F F$ component at $\mathrm{pH} 12.5$, compared to the $F$ component at $\mathrm{pH} 7.5$. Thus, the enzyme broke both chains at once. S component (either native or produced from the action of DNAase on the $F$ component): At either $\mathrm{pH}$ the band formed was modified in the same qualitative way by DNAase; the band became wider, and then its average velocity of sedimentation progressively decreased, as digestion proceeded. The effect was, however, much more pronounced at $\mathrm{pH} 12.5$.

To compare the effects observed at the two $\mathrm{pHs}$, the number of scissions was evaluated from the sedimentation behavior of the DNA molecules. When the number of scissions was low, it was evaluated by determining the proportion of material remaining in a position coincident with the $S$ band ( $\mathrm{pH}$ 7.5) or with the $S F$ band $(\mathrm{pH}$ 12.5). When the number of scissions was higher, it was evaluated from the change in average velocity of sedimentation, ${ }^{14}$ with the assumption that the sedimentation velocity is proportional to $\mathrm{MW}^{0.37}$ at $\mathrm{pH} 7.5$, and to $\mathrm{MW}{ }^{0.5}$ at $\mathrm{pH} 12.5 .^{15}$ In repeated experiments it was found that single-chain cuts, demonstrable at $\mathrm{pH}$ 12.5, were produced at a much faster rate than complete scissions, demonstrable at $\mathrm{pH} 7.5$; and furthermore, that complete scissions occurred according to a kinetics which appeared to be'of higher order (Fig. 8).

These results show that there is a profound difference in the effect of DNAase on the $F$ and on the $S$ component.

The interpretation of these results is that the ring molecules are labile for reasons related to their shape. Perhaps the ring form imposes a statistically higher stress on the phosphodiester bonds; hydrolysis of one bond may increase considerably the stress on the complementary bond, making it highly susceptible to hydrolysis by the same enzyme molecule, or to breakage. As soon as the ring opens, the stress disappears. 


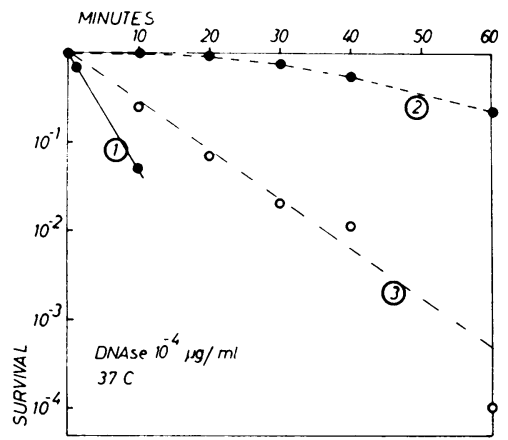

Fig. 8.-Kinetics of DNAase digestion on $\mathrm{H}^{3}$-labeled PY DNA containing almost exclusively $F$ component. All rates were determined within a single experiment, by using a single sample which contained DNA, 15 $\mu \mathrm{g} / \mathrm{ml}$ and DNAase, $10^{-4} \mu \mathrm{g} / \mathrm{ml}$. Survival $=$ proportion of the respective form that remained unchanged. Curve 1: kinetics of disappearance of $F(\mathrm{pH}$ of sedimentation $7.5)$ or $F F(\mathrm{pH}$ of sedimentation 12.5). Curve 2: kinetics of degradation of $S$ (derived from $F$ ); $\mathrm{pH}$ of sedimentation 7.5. Curve 3: kinetics of degradation of $S F ; \mathrm{pH}$ of sedimentation 12.5. In Curves 2 and 3 low survivals were calculated from the average number of scissions per molecule, according to the equation: survival $=\exp (-$ average number of scissions).

Effect of DNAase on infectivity: These experiments yielded two types of results. The first result is that the infectivity of the DNA of the $F$ band decreased as a function of the time of exposure to DNAase at exactly the same rate as the radioactivity. This shows that the infectious molecules have the same properties as the bulk of the DNA molecules. Experiments carried out with pure $F$ component showed that not more than 10 per cent of the infectivity lost by the $F$ component appeared in the $S$ band. Thus, $F \rightarrow S$ conversion by DNAase entails loss of infectivity in most, if not all, molecules.

The other result is that the infectivity of the $S$ component was more resistant to the action of DNAase than that of the $F$ component. The number of hits in the $S$ component determined from infectivity loss corresponded to the average number of complete scissions per molecule, as determined from the sedimentation behavior. With increasing exposure to DNAase, as the radioactivity band increased in width, the residual infectivity remained associated with molecules which sedimented like those of the frontal part of the original $S$ band.

These results show that in both the $F$ and the $S$ components loss of infectivity was caused by complete scissions, whereas single-chain breaks were inconsequential. Single-chain cuts had, however, an effect on infectivity, if DNA which had experienced a few DNAase hits was heated at $100^{\circ} \mathrm{C}$ for $5 \mathrm{~min}$ in $0.15 \mathrm{M} \mathrm{NaCl}$. This DNA lost all its residual infectivity, in contrast to DNA not exposed to DNAase which increased its infective titer two or three times after heating. ${ }^{1}$

Conclusions.-The results here reported are in agreement with the hypothesis that the DNA of polyoma virus is a ring molecule. Many other possible structures which may account for the existence of two components of different sedimentation velocity are contradicted by the results.

According to the results, the ring should be made up of two complete complementary strands, each one separately closed on itself, plectonemically coiled, and not cross-linked. It is likely that the ends of each polynucleotide chain are connected by a special "linker," as in $\phi \mathrm{X}$ DNA. ${ }^{13}$ This is suggested by the presence of infectivity in the native linear molecules, in contrast to its absence in at least most of the linear molecules obtained by DNAase treatment. These results also show that infectivity requires the information of the whole DNA molecule and the integrity of its functional units.

Single-chain breaks, as produced by DNAase in infectious $S$ molecules, do not abolish infectivity. Thus, either these breaks are repaired after the DNA enters 
the cell, or the reading of the DNA molecules for RNA synthesis or replication is undisturbed by the breaks.

The behavior of infectivity at alkali $\mathrm{pH}$ suggests that single-stranded rings are infectious; only further experiments may, however, decide whether this is true.

Two results remain to be explained: (1) the difference in sedimentation velocity of the ring and of the linear molecules is larger than for other ring-shaped molecules, such as those of $\phi \mathrm{X} \mathrm{DNA}^{12}$ or $\lambda \mathrm{DNA}^{16}$ (2) the ring is unstable, as suggested by the kinetics of DNAase digestion. It can be tentatively suggested that they are the consequence of the combination of double strandedness and of the size of the ring.

We are grateful to Prof. R. L. Sinsheimer for useful discussions. The competent and dedicated assistance of Miss Maureen Muir is gratefully acknowledged.

This work will be supplemented by studies with the analytical ultracentrifuge. ${ }^{17}$

* Aided by grants from the National Institutes of Health, U.S. Public Health Service, the American Cancer Society, and The National Foundation.

† Present address: The Salk Institute for Biological Studies, La Jolla, California.

1 Weil, R., these Proceedings, 49, 480 (1963).

${ }^{2}$ Crawford, I. V., Virology, 19, 279 (1963).

3 Watson, J. D., and J. W. Littlefield, J. Mol. Biol., 2, 161 (1960).

4 Winocour, E., Virology, 19, 158 (1963).

5 Weil, R., Virology, 14, 46 (1961).

6 Vinograd, J., R. Bruner, R. Kent, and J. Weigle, these Proceedings, 49, 902 (1963).

${ }^{7}$ Vinograd, J., J. Morris, N. Davidson, and W. F. Dove, Jr., these Proceedings, 49, 12 (1963).

${ }^{8}$ Mandell, J. D., and A. D. Hershey, Anal. Biochem., 1, 66 (1960).

9 Lehman, I. R., J. Biol. Chem. 235, 1479 (1960).

${ }^{10}$ Fiers, W., and R. L. Sinsheimer, J. Mol. Biol., 5, 408 (1962).

${ }^{11}$ Freifelder, D., and P. F. Davidson, Biophys. J., 3, 49 (1963).

12 Sinsheimer, R. L., J. Mol. Biol., 1, 43 (1959).

${ }^{13}$ Fiers, W., and R. L. Sinsheimer, J. Mol. Biol., 5, 424 (1962).

14 Thomas, C. A., J. Am. Chem. Soc., 78, 1861 (1956).

15 Doty, P., J. Marmur, J. Eigner, and C. Schildkraut, these Proceedings, 46, 461 (1960).

${ }^{16}$ Hershey, A. D., E. Burgi, and L. Ingraham, these Proceedings, 49, 748 (1963).

17 Weil, R., and J. Vinograd, in preparation.

\section{THE ROLE OF PROTEIN AND NUCLEIC ACID SYNTHESIS IN THE DEVELOPMENT OF RESPIRATION IN POTATO TUBER SLICES*}

\section{By Robert E. Click and David P. Hackett}

DEPARTMENT OF BIOCHEMISTRY, UNIVERSITY OF CALIFORNIA, BERKELEY

Communicated by W. Z. Hassid, June 13, 1963

The "wound respiration" of potato tubers has been under investigation for more than 75 years, ${ }^{1}$ and attention has recently been focused on the changes which take place when thin slices of this tissue are maintained aerobically. Within a day after cutting, there are striking quantitative and qualitative changes in the respiration: the rate of oxygen consumption increases approximately fourfold, and the respiration becomes relatively insensitive to carbon monoxide and cyanide. ${ }^{2}$ Some of the factors which influence these changes have been investigated, ${ }^{3}$ but the under- 